\title{
REFERENCIA Y AUTORREFERENCIA: LA PRÁCTICA METAPOÉTICA EN LA ESCRITURA DE GUILLERMO CARNERO
}

\author{
Marta Beatriz Ferrari \\ Universidad Nacional de Mar del Plata. Buenos Aires. Argentina.
}

La poesía escrita en España en lo que va del siglo revela claramente una preferencia indiscutida por las formas autorreflexivas y es por ello que en el presente trabajo intentaremos abordar dicha problemática.

Si bien la práctica metapoética aparece tempranamente en el discurso literario español del siglo XX en la obra de Juan Ramón Jiménez como continuador del programa romántico becqueriano y en representantes de la vanguardia de los ' 20 como es el caso de Jorge Guillén o Pedro Salinas, es -creemos- a partir del discurso poético de posguerra que la forma autorrefleja del poema deja de ser un tópico más para convertirse en el modo mismo de construcción del poema, una problemática que recubre la totalidad de la estructuración y los planteamientos del texto literario.

Dentro de este panorama, en la escritura poética de Guillermo Carnero la reflexión autorreferencial ocupa un sitio de privilegio. $Y$ es, precisamente por este carácter dominante que proponemos un acercamiento a dicha práctica.

Si partimos del supuesto de que la metaliteratura propiamente dicha se caracteriza por el hecho de que la reflexión sobre la literatura no es un aspecto más dentro de muchos sino que, por el contrario, se convierte en principio estructurador (factor constructivo, diriamos con Tinianov) del sentido 
del texto, podemos afirmar que el discurso poético de Carnero, a través de la redundancia sémica, articula una reflexión sistemática sobre el lenguaje poético, sus límites, sus alcances. Reflexión que nos permitiría formular una primera hipótesis: la rección semántica que implica esta vuelta obsesiva del discurso sobre sí mismo alentaría a pensar en el surgimiento de una propuesta poética según la cual, la supuesta "autonomía" del texto respecto de la praxis vital deja de revestir el perfil trascendente de las poéticas "modernas" - su gesto utópico sustentado en el poder demiúrgico de la palabra - para emerger paradójicamente como un claro programa desmitificador de dicho lenguaje y hasta de la funcionalidad de la poesía misma. Las conclusiones apuntan a señalar que dicho discurso autorreferencial —en los más claros exponentes de esta escritura del ' 70 - comienza a diseñar progresivamente los contornos de la que será una profunda crisis de orden semiótico según la cual el signo - ambiguo y opaco- llegará a poner en cuestión la capacidad representacional y comunicacional del lenguaje.

La escritura de Guillermo Carnero oscila entre un grupo de poemas de sujeto explícito, en los que el "yo" emerge encarnando la figura de poeta - de fuerte impronta desmitificadora en cuanto al trascendentalismo del arte y la concepción del lenguaje- y aquellos otros en los cuales el sujeto adquiere diferentes modulaciones, ya sea que la voz se disperse en otras voces, se enmascare detrás de otras identidades o bien apele a la figuración de la muerte del "yo".

A través de Orfeo, encarnación mitológica de la figura del poeta, este último emerge - en continuidad con las tesis platónicas - como un fabulador de segundo grado: "Nunca cupo virtud al traficante/que traslada sus males al espejo /admira la pureza de esos seres segundos/y su diversidad taxonomiza" (137) cuyo oficio consiste en paralizar y clasificar a través del discurso poético la dinámica variedad de lo real.

En varios poemas de El sueño de Escipión el ejercicio de la memoria aparece como mecanismo activador de la creación poética. Sin embargo, ese pasado recuperado en la palabra, lejos de captar la esencia de lo real y lejos también de revivir esa experiencia, se transforma en materia inerte disecada por el lenguaje: "Hay colores o músicas/que llevan hacia noches en que el calor de un cuerpo era toda razón: motivo ahora/de construcción poética" (140). La poesía es entendida como un producto artificialmente constituido; el poeta será el "constructor de frases" (141). Esta noción del poeta y del poema se vincula directamente con la idea del poeta como "alquimista" y de 
la poesía como alquimia. Si la poesía es entendida como el arte de transmutar lo vivo en otra cosa, de convertir lo real en materia poética, el poema será el producto resultante de múltiples operaciones combinatorias. La incorporación de recursos intertextuales, la yuxtaposición de sistemas semióticos en el cuerpo del poema responden a esta concepción alquímica del arte poética.

Los poemas de Carnero surgen, entonces, como un segundo lenguaje redundante, como una reduplicación de una experiencia estética ya plasmada en una obra artística previa. El referente del poema vuelve a ser un producto cultural; se crea así un circuito cerrado, un círculo de referencias indefinidas que no logra trascender los límites de un universo definido estéticamente. La vinculación con "lo real" parece si no imposible, al menos no declaradamente necesaria. El carácter circular y, por ende clausurado del discurso poético en Carnero se advierte claramente en el poema que da título al libro, "El sueño de Escipión". En él, el sujeto intenta obtener una definición acerca del "ser" del poema "Poema es una hipótesis sobre el amor escrito/por el mismo poema" (152). Desde el momento en que el signo no remite a nada fuera de sí mismo e, incluso, lo exterior al signo está puesto en duda, el poema vuelve a definirse como una ficción de segundo grado. El recurso metapoético -en el caso particular de la escritura de Carnero- lejos de reforzar la condición autónoma del texto, habla más bien, de una inevitable clausura del discurso sobre sí mismo, de una reflexión que deviene necesariamente tautológica y que al hacerlo, redefine críticamente sus propios mecanismos expresivos, poniendo en cuestión al mismo discurso y sus modos de comunicación.

La ficción inherente al arte en general afecta, de este modo, al arte poético que surgirá en su dimensión de simulacro y de convención socialmente instituida: "Las estatuas sugieren/ un alma a este jardín, no su pasado mismo/sino la vaga realidad que me complace ahora/ inventar en su honor, y la emoción poética/ más que de sabia precisión da fe/de una cierta ignorancia convenida/ a modo de verdad" (129).

La práctica metapoética de Carnero extrema la tensión existente entre la teoría y la práctica literaria. A esta tensión viene a añadirse una segunda cuestión, la tensión entre la realidad y la ficción. Críticos como Patricia Waugh (Metafiction:the theory and practice of self-conscious fiction, New York, Routledge,1988) definen precisamente a la metaliteratura "como un término dado al discurso ficcional que sistemáticamente dirige la atención hacia su condición de artefacto a fin de cuestionar la relación entre ficción y realidad". Un texto, entonces, que desenmascara y problematiza su carácter ficcional. 
El sujeto que construye la escritura de Carnero es un sujeto eminentemente perceptivo. Esto nos remite al ámbito de pertenencia de una "teoría de la visión". Señalemos aquí que el título bajo el cual se agrupa la casi totalidad de la obra poética de Carnero, Ensayo de una teoria de la visión es, a su vez, un intertexto berkeliano, An Essay Towards a New Theory of Vision. La filiación del pensamiento poético de Carnero con las tesis filosóficas de George Berkeley es evidente más allá de esta cuestión paratextual. La defensa de la percepción - y de ahí la insistencia en una "teoría de la visión" - como principio de todo conocimiento y el papel fundamental que en ella representan las expresiones lingüisticas por medio de las cuales se estiman las cosas vistas son ideas vastamente desarrolladas por el discurso de Carnero.

Esta capacidad perceptiva que supone la aprehensión directa y concreta de "lo visible" sin intermediación lingüística -"donde todo es presencia como el yute o el cánamo" (163) - se erigirá en un deseo dominante en su escritura: "El discurso poético/ fueran haces de signos surgidos en el aire, /emanación/de la presencia pura de volúmenes juntos/ o colores o masas" (162). Un deseo cuya consecución se revela imposible: "no hay palabras ni cuerpos nacidos en el aire" (163). La idea, por tanto, del lenguaje como materia impura - "La sordidez es nuestro pan, /origen del discurso que llamamos poema" (162) - será el tema de la primera Variación: "Domus aurea". En él, un hablante plural aboga por la inmaterialidad del lenguaje, un lenguaje hecho sólo de significantes, un lenguaje que nada signifique; deseo que ya había sido manifestado en "Rodéanos de rápidos desnudos": "escritura o deseo: escoger un lenguaje/con que nunca nombrar: su función íntima" (145). La opacidad e impureza del lenguaje derivan de su inevitable carga semántica,de su pretensión por significar:

“...la roca

es una arista dócil a la mano

$\tan$ irreconocible que carece

de partes,a lo sumo es un color

extenso, que ante el mar no significa

y sonoro en las olas que no tienen historia,

no así el poema : viejos estandartes

llamados a contar siempre la misma hazaña intentando la

música que los cuerpos omiten

y enturbian las palabras con su fango (163). 
La segunda Variación, "Queluz", es un ensayo de conceptualización; un intento de definición de lo "real" prescindiendo del lenguaje que lo nombra. La propuesta del sujeto es, entonces, expresar la cosa a partir de la enunciación de sus cualidades - volumen, distancia, color. Si "ser es percibir y ser percibido", la esencia de lo real estará contenida en las propiedades visibles al ojo humano "luz sin forma aún, luego es esfera/de color: y si define en luz, no tiene nombre" (165). Se aboga así por una percepción directa del objeto, sin mediación del lenguaj: "Si llegaste a advertir lo que no tiene nombre", pero esto se revela como otra imposibilidad: "regresas luego a dárselo". Aquí reside la paradoja del discurso de Carnero: luchar contra el mismo instrumento con el cual se ataca y se lucha. El lenguaje se revela como única vía posible de acceso a lo real y el único también con el que se puede cuestionar dicho modo de conocimiento. Al acentuar el carácter inevitable de la formulación lingüística, la escritura de Carnero coloca en situación de extrema tensión la capacidad significadora del lenguaje. El lenguaje sólo podrá ser metalenguaje, por lo tanto, esta escritura se volverá sobre sí misma, hablará de sí misma, se convertirá en "metapoesía" al hacer continua referencia a la creación poética, al lenguaje y al propio poema.

Todo el pensamiento poético de Carnero parece articularse sobre una concepción del lenguaje fundada en la azarosa relación existente entre signo/cosa. A partir de esta comprobación el sujeto textual se debatirá entre diversos intentos por buscar "esa evidencia/con que un objeto atrae a la palabra propia/y el uno al otro se revelan" (177); búsqueda infructuosa de un lenguaje "motivado" y "esencial". La no consecución de este deseo define la paradoja de la escritura carneriana. No es la "cosa" la que atrae necesariamente a la palabra que la nombra, sino que las palabras se atraen entre sí tejiendo una red sonora que a nada remite. Si el lenguaje es incapaz de referir nada exterior a sí mismo, se destruye la idea del arte en tanto representación de lo real.

En el poema titulado "Discurso del método", la frialdad de la enunciación, la total ausencia de sentimentalismo emerge de una voz -como indica el título - cartesiana y analítica. El buscado prosaísmo - la imitación de las modalidades del discurso técnico o filosófico sin rastros del lenguaje convencionalmente denominado "poético" - contrasta con la definición que se da en el primer verso: "En este poema se evitará..." (157), la afirmación de que,a pesar de estar frente a un texto que roza con el antipoema, se trata, de todos modos, de poesía. $\mathrm{El}$ indicador metatextual de género establece aquí 
un evidente contraste entre el afirmado carácter poético del texto y su aparente carácter de prosa científica.La función de dicho indicador no es orientar la lectura del poema como tal sino que pone de manifiesto su carácter complejo y propone a la ironía como clave de lectura. Paralelamente el poema va diseñando la figura del lector potencial de estos versos: "quien pueda leerlos en su verdadero sentido/tendrá igualmente presente su contexto". Se dibuja así el perfil de un lector competente, especializado. El mismo Carnero afirma respecto de las escrituras "novísimas": "Estos procedimientos reducen el campo de posibles lectores; esto exige del lector la posesión de un repertorio cultural semejante al del autor o bien, un esfuerzo de documentación previa a la lectura. (Culturalismo y poesía novísima, Madrid, Orígenes, 1991 p. 21). Esta pose erudita y culturalista, sin embargo, es defraudada por el mismo sujeto al dar como producto un encadenamiento poemático que burla las expectativas de ese lector "competente" que cada uno de estos textos construye . La práctica metaliteraria no sólo disuelve así los límites entre la literatura y la reflexión sobre la literatura sino que además expone una profunda revisión del código literario mismo y, al quebrar las expectativas genéricas del lector, presupone el surgimiento de nuevas estrategias de decodificación por parte del receptor. El discurso autorreferencial al volver críticamente sobre los propios modos de construcción del texto, alerta acerca del carácter de artificio del texto literario. Contrariamente a las pretensiones de la poesía de corte simbolista-modernista, cuando el texto quería ser una emergencia "ex nihilo" de la sola subjetividad del emisor, estas escrituras subrayan la dimensión de constructo del texto literario al exhibir deliberadamente los mecanismos de producción del significado del texto, poniendo el énfasis en el proceso de significación más que en el producto final.

Como bien señala Leopoldo Sánchez Torre en La poesía en el espejo del poema (1993): "La primera paradoja del discurso metapoético es que su forma no poética oculta, enmascara, desvanece su condición de discurso poético", sin embargo, aclara: "ese enmascaramiento no anula el carácter poético del metapoema". No acordamos, sin embargo, con la interpretación central que el autor realiza de la práctica metapoética "novísima", reduciendo la reflexión sobre la insuficiencia del lenguaje al "viejo tópico de lo indecible y de la cortedad del decir de Dante". En el ámbito de la crítica hispánica, la de Amparo Amorós Moltó ha sido una de las pocas voces que han interpretado el verdadero alcance de esta práctica metapoética. Amorós ha interpretado a la tarea poética como una experiencia real de los límites del lenguaje, en clara 
línea de continuidad con las tesis de Mattei Calinescu quien en su obra Five faces of Modernity se pregunta: "Sentada la radical duda epistemológica de nuestros días y el modo en que esta duda afecta al estatus de "representación" ,puede la literatura ser otra cosa que autoreferencial? Puede decirse que la literatura es "representación de la realidad" cuando la realidad misma está siendo permanentemente acechada por la ficción?" (Margaret Persin, "La imagen del / en el texto :el ekfrasis, lo postmoderno y la poesía española del siglo XX" en Novtsimos, Postnovisimos, clásicos. La poesía de los 80 en España, Ed. Biruté Ciplijauskaité, 1991.

Para sintetizar señalemos, una vez más, el carácter paradójico que reviste la meditación de Carnero, una especulación que intenta poner en cuestión la esencia misma del material con el cual trabaja. Su escritura coloca así en situación de extrema crisis la capacidad referencial del lenguaje. El lenguaje reducido a metalenguaje sólo puede conducir inevitablemente al silencio. Se trata de un arte cuya materia lingüística ha perdido su capacidad simbólica para presentarse en su ambigua condición de signo precario, insuficiente y arbitrario incapaz de referir la realidad: "Producir un discurso - afirma Carnero en el poema que cierra Ensayo de una Teoría de la Visión- ya no es signo de vida, es la prueba mejor de su terminación" (208). 